\title{
Alterations of riverine ecosystems adversely affect bird assemblages
}

\author{
Tomasz Figarski • Lukasz Kajtoch
}

Received: 28 March 2014/Revised: 8 October 2014/Accepted: 12 October 2014/Published online: 5 November 2014

(C) The Author(s) 2014. This article is published with open access at Springerlink.com

\begin{abstract}
The alteration of flow regimes is the most serious threat to the environment and populations of riverine ecosystems. The aim of this study was to verify how newly recovered assemblages of riverine birds react to recent and intensive water control transformations. Data on habitat transformations, breeding bird species and population abundance within submontane river channels in southern Poland were compared before and after river regulation. Regulation works affected approximately one-third of river sections in the drainages studied. Simultaneously, large amounts of gravel, clay and woody debris were removed from river channels, and river channels became overgrown by dense vegetation. Regulation works carried out in river channels, previously restored by severe flood, led to a strong decline in breeding bird assemblages $(23 \%$ decrease of species richness and $33 \%$ decrease of population abundance). These results show that river regulation can significantly alter the structure of breeding bird
\end{abstract}

Handling editor: Stuart Anthony Halse

Electronic supplementary material The online version of this article (doi:10.1007/s10750-014-2084-1) contains supplementary material, which is available to authorized users.

T. Figarski $(\bowtie) \cdot$ Ł. Kajtoch

Institute of Systematics and Evolution of Animals, Polish Academy of Sciences, 17 Sławkowska, 31-016 Cracow, Poland

e-mail: tomasz.figarski.isez@gmail.com assemblages, and such change is generally negative for bird diversity (especially for rare and vulnerable species). Riverine habitats are some of the most important biodiversity hotspots and major routes of migration for organisms in Europe, so the degradation of riverine ecosystems can have a catastrophic impact on nature in the entire European Union.

Keywords River regulation $\cdot$ Flood $\cdot$ Bird assemblages $\cdot$ Habitat guild $\cdot$ Biodiversity

\section{Introduction}

The alteration of flow regimes is the most serious threat to the environment and populations of riverine ecosystems (Naiman et al., 1995; Sparks, 1995; Ward et al., 1999). Humans have expended great effort to regulate watercourses to improve their value for transportation, water supply, flood control, agriculture and power generation. However, anthropogenic alterations of riverine ecosystems change the established pattern of natural hydrologic dynamics and create new artificial conditions to which native species may be poorly adapted (NRC, 1992; Naiman et al., 1995). The extensive ecological degradation and loss of biological diversity, resulting from river regulation, have been eliciting widespread concern among naturalists and some members of the public (Karr et al., 1985; Hughes \& Noss, 1992; Allan \& Flecker, 1993; 
Williams, 1996). Decades of observation of the effects of human alteration of natural flow regimes have provided explanations of why altering hydrologic variability in rivers is ecologically harmful (e.g. Johnson et al., 1976; Tyus, 1990; Arthington et al., 1991; Hill et al., 1991; Sparks, 1995; Toth, 1995; Castleberry et al., 1996; Stanford et al., 1996; Richter et al., 1997). Other studies have shown the harmful effects of altering flow by constraining rivers with artificial levees, dikes or groynes (e.g. reviews in Nilsson \& Dynesius, 1994; Nilsson \& Berggren, 2000). However, most of these studies have focused on floodplain habitats (marshes, riparian forests, etc.) or species inhabiting floodplains (e.g. Kingsford \& Thomas, 2004; DesGranges et al., 2006), and there has been less emphasis on riverine (river channel) communities and taxa. Moreover, there are no studies describing the reaction of species or assemblages to river regulation that has occurred shortly after natural disturbance and population recovery.

The restoration of riverine habitat and recovery of riparian animal populations after flooding are difficult to study because of the long time-scales usually required to observe change. However, some studies have shown that natural or man-made floods can lead to habitat restoration and consequently to population recovery (e.g. floodplain birds-Rood et al., 2003; river channel birds-Kajtoch \& Figarski, 2013). This is achieved through flood pulses removing man-made installations (levees, dikes and groynes) and restoring natural elements of river channels (gravel or sandy alluvia and scarps covered by pioneer vegetation and deadwood debris). Here, we used this phenomenonthe restoration of riverine bird assemblages after the severe flood that took place in 2010 in central Europeas the starting point for further research. Just after this riverine habitat recovery, intensive regulation and water control actions started, concentrated mainly on river systems in southern Poland that had been severely impacted by the flood of 2010. Riverine habitats (pioneer vegetation on alluvia, scarps and deadwood debris) were substantially transformed by river embankment works as well as by the removal of gravel and wood from river channels. Regulation and control actions involved the protection of riverbanks and also often the bottom of channels from water erosion with use of large stones integrated by steel nets. This alteration was often accompanied by the removal of gravel and wood to clear river channels and facilitate water flow. These actions force water to flow within a narrow "stony" channel and resulted in rapid overgrowth of the former natural channel by dense vegetation. These actions took place in the autumn-winter of 2011/2012 (after the breeding season of 2011 and before the season of 2012).

Birds may be ideal models for studies of changes to biological assemblages in a particular type of environment because they are often numerous, exhibit many clearly understood ecological traits (e.g. different habitat and food preferences), and can be easily detected and counted in the field. Furthermore, bird species or assemblages have been shown to be good indicators of environmental quality in many situations (e.g. Croonquist \& Brooks, 1991; Bryce et al., 2002; Frederick et al., 2009; Kajtoch et al., 2014) and may be keystone species (Paine, 1969; Mills et al., 1993).

The aim of this study was to verify how newly recovered assemblages of riverine birds react to recent and intensive water control transformations. In particular, this study tested the hypothesis that riverine bird assemblages react negatively (in terms of both species composition and population abundance) to changes in river channels caused by regulation works.

\section{Methods}

Study design

The study was conducted along the submontane river channels of the Raba River and Dunajec River basins in the northern margin of the Western Carpathians and across the foothills of the Western Carpathians in Małopolska Voivodeship (southern Poland). A detailed description of the study area as well as the study design was presented in Kajtoch \& Figarski (2013). In summary, both river systems occur in Carpathian Foothills and the river channels have hydromorphologies and habitats typical of mediumsized submontane rivers: braided channels with gravel islands covered by pioneer, scarce riverine vegetation and accumulated deadwood and surrounded by clay scarps. These diverse habitats are settled by birds adapted to breed on gravel or in hollows in uprooted trees or in river scarps, but not used by species that depend on marshes or stagnant waters. Since 2000 or 2005 (depending on which parts of the river basins are being considered), bird monitoring has been 
conducted in river valleys, including river channels, as part of a larger study (Kajtoch \& PiestrzyńskaKajtoch, 2008; Kajtoch, 2012). Birds were inventoried in 16 river sections, each $1 \mathrm{~km}$ in length. Data of bird species richness and abundance from immediately prior to regulation (2011, 1 year after the severe flood) and the post-regulation (2012, a few months after regulation works) were collected using the same techniques as in Kajtoch \& Figarski (2013). Breeding birds (only bird species and pairs breeding inside river channels) were mapped along $1 \mathrm{~km}$ transects within the river channels according to mapping techniques (e.g. Bibby et al., 2000; Gregory et al., 2004). All river sections were surveyed five times during the breeding season (April-July). Mapped localities of breeding pairs from all five surveys were used for identification of breeding territories, and the total number of these territories (for each species in each section) was then counted. For each section, the change of species number and species abundance between the 2011 and 2012 breeding seasons were calculated.

Five variables were measured in 2011 and 2012 within the $1 \mathrm{~km}$ river sections to provide data on changes in river habitat. These variables were the changes of: occurrence of river regulation (REGULATION), alluvium resulted from gravel excavation (ALLUVIUM), scarp resulted from scarp levelling (SCARP), wood amount (WOOD) and vegetation succession (VEGETATION). REGULATION was measured as proportion of the $1 \mathrm{~km}$ lengths of river sections affected by this activity. ALLUVIUM and SCARP were measured as change of proportions of the $1 \mathrm{~km}$ lengths of river sections containing each variable, wood was calculated as a change of proportion of river section in which wood (mostly deadwood) was present. As wood was distributed unevenly in river channels, being accumulated mainly in bends in the river, we divided the $1 \mathrm{~km}$ river sections into 50-m subsections and scored wood as present if any wood occurred in the fragment. Analyses were based on the percentage of subsections containing wood. VEGETATION was measured by plotting the occurrence of dense vegetation greater than 0.5 metres on simplified river maps and calculating the cover (mainly native Blueweed Echium sp. and Mullein Verbascum sp. and/or invasive Goldenrod Solidago sp.) within the section, to estimate percentage cover. Most analyses examined the change in percentage cover of the different environmental variables between 2011 and 2012 .
Statistical analyses

Differences between species richness and population abundance between prior to and post-regulation were assessed using the Wilcoxon signed-rank test. The significance of correlations between different variables was calculated using the Spearman's rank correlation tests. For detailed analysis, bird species were divided into habitat guilds: alluvium-dwellers (breeding on river alluvia) and bank-dwellers (ones connected with riverbank structures and scarps, including uprooted trees) (8 and 7 species, respectively).

The influence of environmental variables on birds was further examined using generalized linear models (GLM) with Poisson distributions. Sets of competing models were built (separately for changes of species richness and changes of population abundances in each guild and for all species) and tested using the akaike information criterion (AIC) (Burnham \& Anderson, 2004). Due to a relatively small sample size and some overdistribution (quasi-likelihood parameter $>1$ ), the modified version of AIC (QAICc) was used (Hurvich \& Tsai, 1991). A multimodel inference, made by summing QAICc weights for models containing given variables, was used to assess the real importance of each independent variable (Burnham \& Anderson, 2002; Freckleton, 2011). All analyses were done with Statistica 10.0 software (StatSoft Polska). In all statistics, a minimum probability level of $P \leq 0.05$ was adopted.

\section{Results}

Fourteen bird species bred within river channels in 2011 , with a mean of $8.0( \pm 0.5 \mathrm{SE})$ and in the range of 5-11 per channel, whereas in the consecutive year 12 species bred (mean $6.1 \pm 0.7$, range 1-11). In total, 15 species bred at least in one of the 2 years studied. In 2011 , the average abundance of pairs was $22.5( \pm 3.6$; range 7-60), but in 2012 it was 16.9 ( \pm 5.5 ; range 2-89). Between 2011 and 2012, three species disappeared locally (Ringed Plover Charadrius hiaticula L., Common Gull Larus canus L. and European Beeeater Merops apiaster L.). Six species showed strong decline (Little-ringed Plover Charadrius dubius Scopoli, Common Sandpiper Actitis hypoleucos L., Common Tern Sterna hirundo L., Black-headed Gull Chroicocephalus ridibundus L., European Dipper 
Cinclus cinclus L. and Common Kingfisher Alcedo atthis L.) and three species showed weak decline (Grey Wagtail Motacilla cinerea Tunstall, Sand Martin Riparia riparia L. and Goosander Mergus merganser L.) (Table 1). On the other hand, the numbers of one species were stable (White Wagtail Motacilla alba L.), one species increased in number (Lapwing Vanellus vanellus L.) and one species started to breed (Yellow Wagtail Motacilla flava L.) (Table 1). Considering habitat guilds, two species of alluvium-dwellers disappeared but one started to breed and one bank-dweller species disappeared. Overall species richness decreased by $24.8 \% \pm 7.4$ (range -86 to 20) as did species richness of alluviumdwellers (average $-26.0 \% \pm 11.2$ ) and bank-dwellers (average $-21.4 \% \pm 8.6$ ). Population abundance in all the sections studied decreased by $32.7 \% \pm 10.8$ (range -87 to 48 ); however, a greater decrease was observed in alluvium-dwellers $(-44.3 \% \pm 10.0)$ than in bank-dwellers $(-22.7 \% \pm 14.8)$. In two sections the numbers of breeding species increased, and in two sections numbers were stable. In the other sections, the number of breeding species declined. The numbers of pairs of breeding birds increased in four sections and declined in the other 12 sections. Differences in species richness and numbers of breeding pairs prior to and after regulation were significant $(Z=2.73$, $P=0.01$ and $Z=1.99, P=0.05$, respectively; Fig. 1). There was also significant correlation between changes in the numbers of breeding species and the numbers of pairs $(\rho=0.68, P<0.01$; Fig. 1$)$. The length of regulated fragments within each river section increased on average of $36.3 \%$ ( $\pm 9.6 \mathrm{SE}$; range 0-100) (in six of them it did not change). The proportion of alluvium decreased on average $51.3 \% \pm 7.2$ (range -100 to 0 ); in only one section did it not decrease. The proportion of scarps decreased on average $46.9 \% \pm 10.6$ (range -100 to 0 ) and did not change in five sections. The amount of wood decreased on average $66.3 \% \pm 7.5(-100$ to -20$)$ and decreased in all sections, whereas vegetation cover increased on average $46.3 \% \pm 7.9$ (range 10-90) and increased in all sections. Bird species and population changes were found to be correlated significantly with most of the above environmental variables. The exceptions were VEGETATION, which was neither correlated with species change nor with pairs change, and ALLUVIUM, which correlated significantly only with species change (Fig. 2).
Table 1 Changes of population abundance of breeding birds in studied valleys (pre- and post-regulation works)

\begin{tabular}{|c|c|c|c|}
\hline Species & $\begin{array}{l}\text { Change } \\
(\%)\end{array}$ & Trend & Habitat guild \\
\hline Charadrius dubius & -40.8 & $\begin{array}{l}\text { Strong } \\
\text { decline }\end{array}$ & $\begin{array}{l}\text { Alluvium- } \\
\text { dwellers }\end{array}$ \\
\hline Charadrius hiaticula & -100.0 & Perish & $\begin{array}{l}\text { Alluvium- } \\
\text { dwellers }\end{array}$ \\
\hline Vanellus vanellus & 12.5 & Increase & $\begin{array}{l}\text { Alluvium- } \\
\text { dwellers }\end{array}$ \\
\hline Actitis hypoleucos & -34.6 & $\begin{array}{l}\text { Strong } \\
\text { decline }\end{array}$ & $\begin{array}{r}\text { Alluvium- } \\
\text { dwellers }\end{array}$ \\
\hline Sterna hirundo & -70.0 & $\begin{array}{l}\text { Strong } \\
\text { decline }\end{array}$ & $\begin{array}{l}\text { Alluvium- } \\
\text { dwellers }\end{array}$ \\
\hline $\begin{array}{l}\text { Chroicocephalus } \\
\text { ridibundus }\end{array}$ & -50.0 & $\begin{array}{l}\text { Strong } \\
\text { decline }\end{array}$ & $\begin{array}{r}\text { Alluvium- } \\
\text { dwellers }\end{array}$ \\
\hline Larus canus & -100.0 & Perish & $\begin{array}{l}\text { Alluvium- } \\
\text { dwellers }\end{array}$ \\
\hline Motacilla flava & - & New & $\begin{array}{l}\text { Alluvium- } \\
\text { dwellers }\end{array}$ \\
\hline Motacilla alba & -4.4 & Stabile & Bank-dwellers \\
\hline Motacilla cinerea & -15.0 & $\begin{array}{l}\text { Weak } \\
\text { decline }\end{array}$ & Bank-dwellers \\
\hline Cinclus cinclus & -50.0 & $\begin{array}{l}\text { Strong } \\
\text { decline }\end{array}$ & Bank-dwellers \\
\hline Mergus merganser & -11.1 & $\begin{array}{l}\text { Weak } \\
\text { decline }\end{array}$ & Bank-dwellers \\
\hline Alcedo atthis & -64.3 & $\begin{array}{l}\text { Strong } \\
\text { decline }\end{array}$ & Bank-dwellers \\
\hline Riparia riparia & -12.8 & $\begin{array}{l}\text { Weak } \\
\text { decline }\end{array}$ & Bank-dwellers \\
\hline Merops apiaster & -100.0 & Perish & Bank-dwellers \\
\hline
\end{tabular}

Considering the changes in the numbers of bird species, the best model according to GLM contained only one variable: REGULATION (QAICc $w=0.07$ ). The same was found when GLMs were calculated for species richness in both habitat guilds (QAICc $w=0.15$ for alluvium-dwellers and QAICc $w=0.16$ for bank-dwellers). In contrast, the change in the numbers of breeding pairs was best explained by a model that contained only wooD (QAICc $w=0.19$ ), although when particular habitat guilds were considered the best model again contained only REGULATION (QAICc $w=0.15$ for alluvium-dwellers and QAICc $w=0.16$ for bank-dwellers). Single-variable models were found to better explain both changes in species richness and numbers of pairs than any of the models with more variables (Supplementary Table 1). Relatively low differences between the best models for all 
Fig. 1 Numbers of species and pairs of birds breeding in studied river valleys comparisons between pre(2011) and post- (2012) regulation works ( $Z$ test) and Spearman-rank correlation between changes of species richness and population abundance of birds breeding in studied valleys ( $\rho$ test)

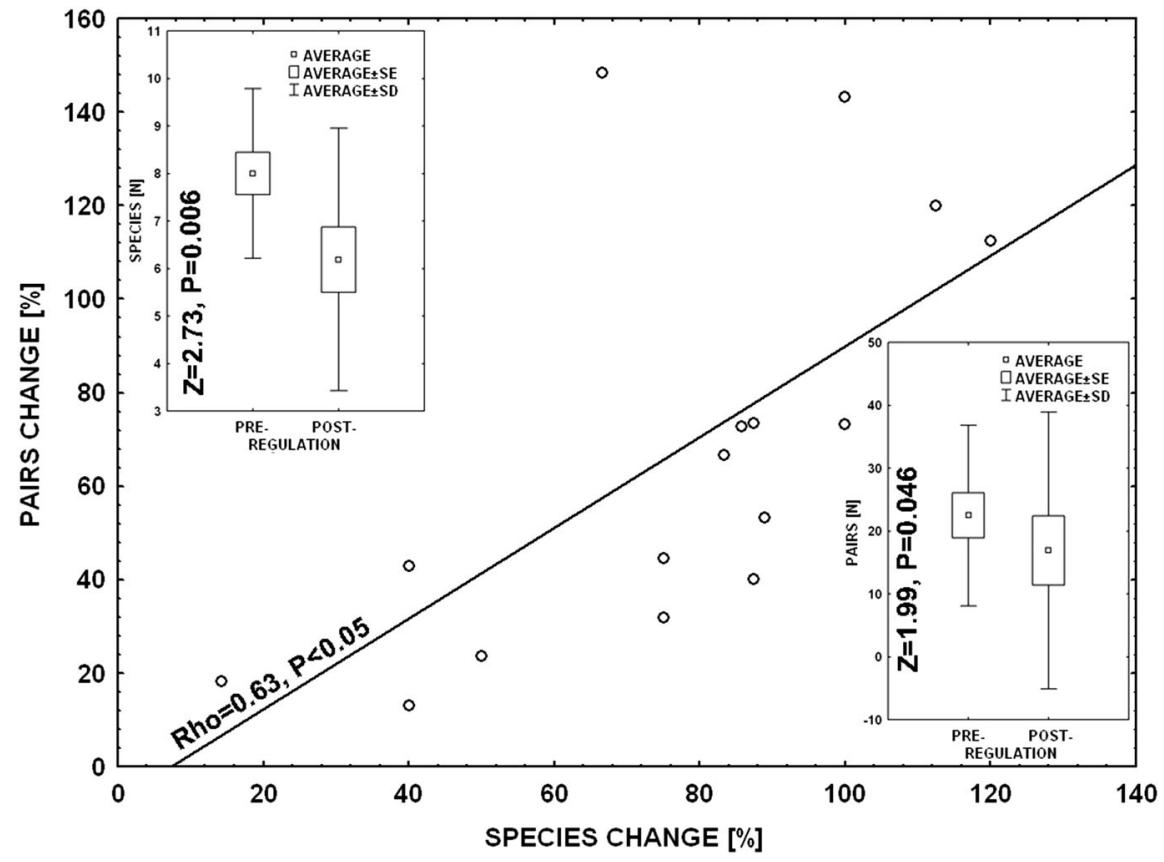

GLM analyses led us to make a multimodel inference in order to check the real explanatory value of each variable (Table 2). Taking into consideration a complete set of candidate models, in which every variable occurred the same number of times, the most valuable variables were REGULATION (best in four of six analyses) and SCARPS.

\section{Discussion}

Regulation works carried out in river channels, previously restored by the severe flood in 2010, led to a strong decline in breeding bird assemblages. Some birds did not breed after these regulation works. In this group were species that had settled for the first time in the studied river channels just after the flood in 2010 (European Bee-eater) or had come back after a long break just after the flood of 2010 (Ringed Plover, Common Gull; Kajtoch, 2012; Kajtoch \& Figarski, 2013). Apparently, restoration of natural habitats of submontane valleys had enabled or facilitated their breeding in the study area and subsequent regulation works ended their breeding. More than half of the species breeding in the studied channels before the regulation works showed decline (strong or weak) in their populations after regulation. Birds breeding in gravel alluvium or in clay scarps were most affected. Species showing only weak decline or stable populations were either abundant in river valleys (grey and white wagtails), can breed colonially in relatively small areas (Sand Martin, which moved colonies into river scarps on unregulated sections and therefore locally increased in density), or are presently expanding in southern Poland (Goosander; Kajtoch \& Bobrek, 2014). It is interesting to note that the only species that showed an increase in numbers of pairsLapwing and the only new breeder in the channels, Yellow Wagtail — are species adapted to wet meadows rather than to river channels. These species reacted positively to river regulations because these works altered the pattern of river inundations and allowed expansion of plants into river channels (including invasive species such as goldenrod), which changed the riverine vegetation of river channels, dependent on the natural hydrological regime, into a more meadowlike environment. This change of vegetation cover also had an impact on other birds, which lost some of their breeding sites not only to river regulation but also to dense plants overgrowing gravel alluvia. Overall bird assemblages of submontane river channels reacted negatively to river regulation and accompanying actions (removal of gravel and wood from river channels, levelling of scarps and, consequently, the 

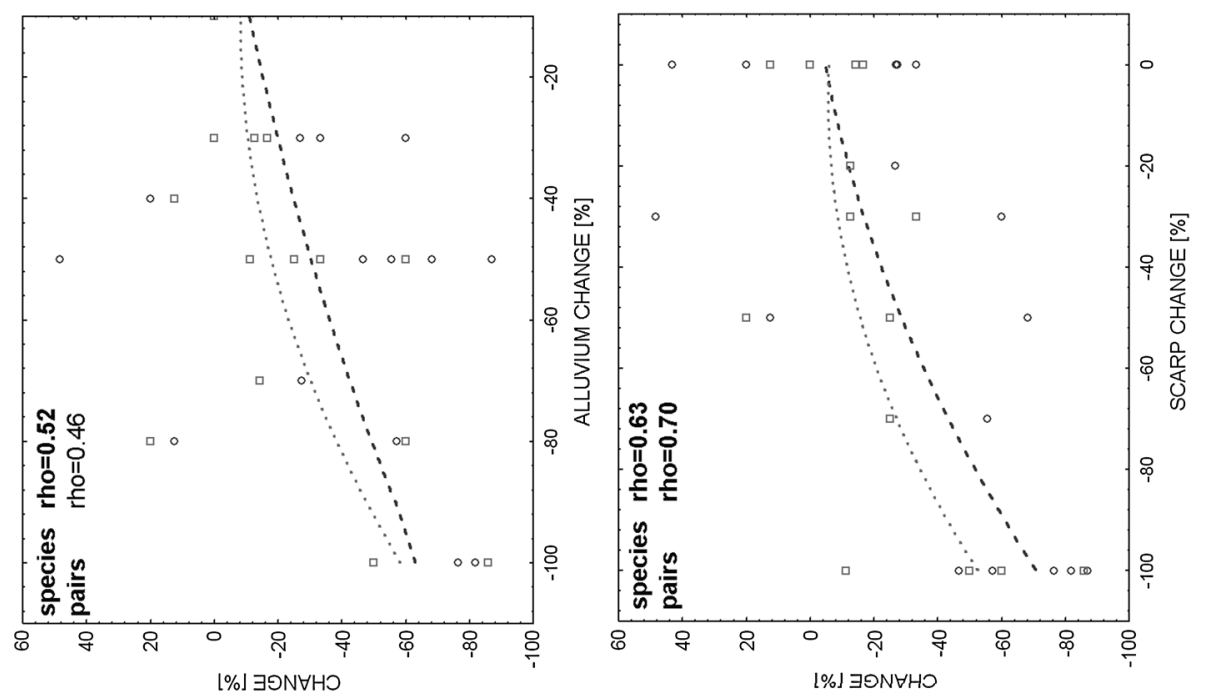

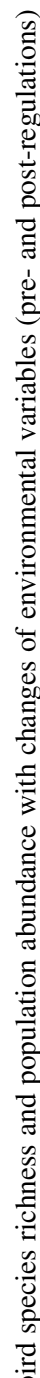
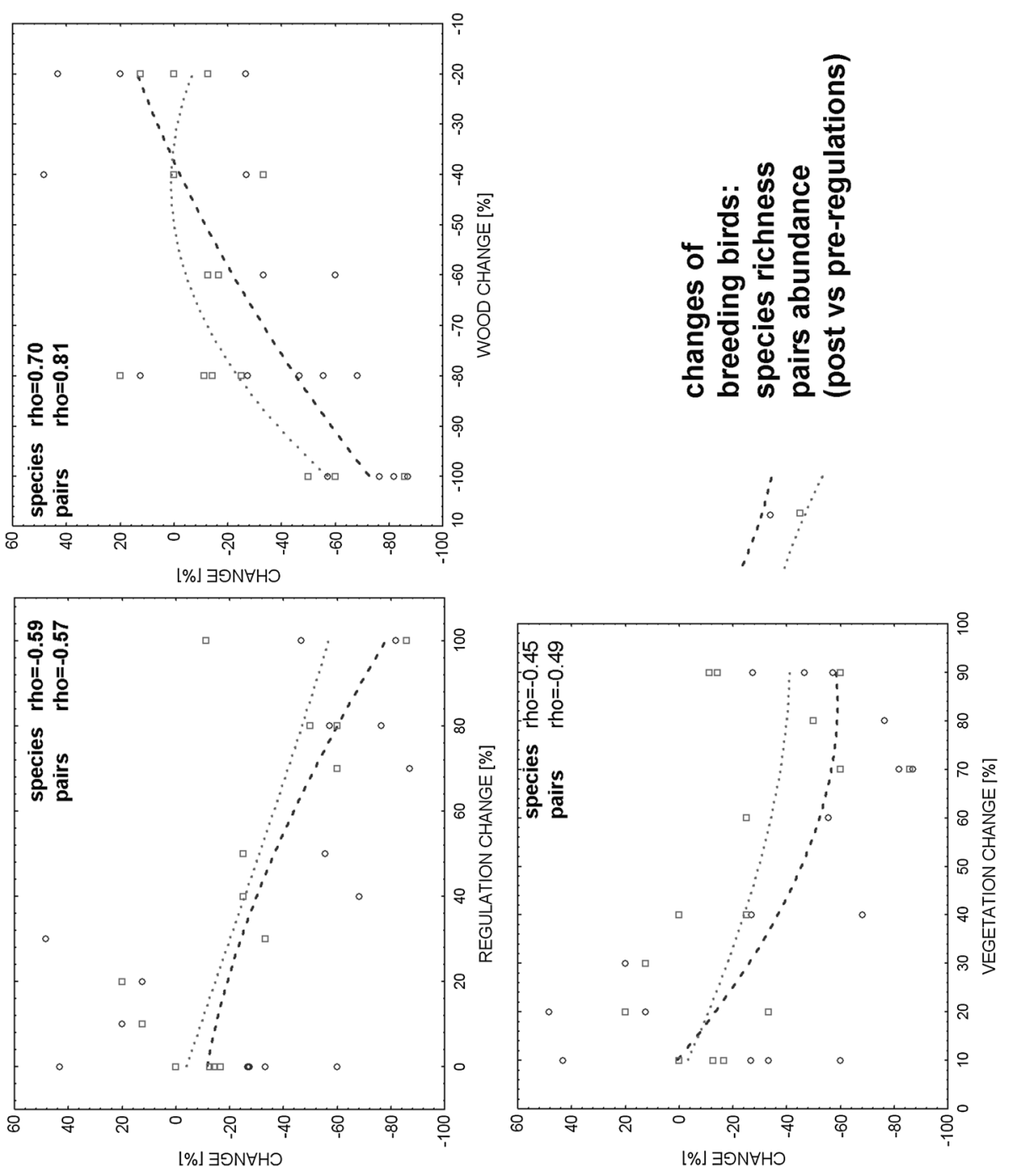
succession of dense vegetation). Breeding populations decreased by, on average, one-third with respect to the pre-regulation period. In some river sections, this decrease was weak or the number of local pairs even increased in number, but this applied only to river sections not regulated between the years 2011 and 2012. This stability or even slight increase in numbers of breeding pairs in these sections suggests that the positive effect of the flood may persist for a longer period of time. On the other hand, in most river sections transformed by water management, bird abundance decreased strongly; in some sections only a few species were left, and in the most severely regulated section only the White Wagtail still bred. It is important to note that the decrease of species richness was correlated significantly with the decrease in numbers of breeding pairs. This shows that birds react to river regulation on two, most likely simultaneous, levels by (i) ceasing to breed and/or (ii) reducing breeding effort and the number of breeding pairs. These responses suggest that birds may be good indicators of river channel habitat quality. Other investigations of the influence of river regulation have examined this effect on birds and also shown negative responses to water control activities or water pollution (e.g. Sorace et al., 2002; Palacio-Núñez et al., 2007; Kingsford \& Thomas, 2004; DesGranges et al., 2006). However, most of the previous studies examined the effects of river regulation on floodplain species as a result of reduced annual inundation. Here, we also show that river channel-dwellers are susceptible to river regulation. This assemblage is particularly vulnerable to water control activities because of the direct impact on bird breeding sites within channels.

Regulation works affected approximately $36 \%$ of river sections in the studied drainages. However, it was not only the regulation of riverbanks and taming that was harmful to birds. Simultaneously, large amounts of gravel, clay and woody debris were removed from river channels (on average $50 \%$ of gravel alluvium and clay scarps were destroyed, and more than $65 \%$ of deadwood was removed). These natural elements of river channels are important breeding sites for birds that breed either on gravel alluvia with scattered vegetation (plovers, terns, gulls), in steep scarps (Sand Martin, Kingfisher, Beeeater, Dipper) or on uprooted trees (wagtails, Goosander). The removal of large amounts of gravel, clay and wood from river channels probably also has a serious impact on birds as these alterations accelerate the effect of regulation of riverbanks.

The most important environmental variable for species change between 2011 and 2012 (as well as for both habitat guilds) was REGULATION. This result proved that regulation works can modify breeding bird species composition and lead to birds perishing. For alluvium-dweller species, just important as REGULATion was VEgEtation. This is expected because the expansion of plants can eliminate some species connected to gravel alluvia (either vegetation-free or covered only with initial vegetation). Observations showed that the level and speed of succession can be quick and considerably influenced species that breed in the above-mentioned structures. On the other hand, a few species benefitted from arising changes (Lapwing and Yellow Wagtail); however, these taxa are not characteristic of the studied habitats and they are numerous in other locales. At the same time, for bankdweller species SCARPS were an important factor in influencing species structure. Species forming this habitat guild take advantage of the heterogeneous microhabitats of natural riverbanks. Such habitats are mostly destroyed during regulation works, so many of them completely lost an opportunity to breed.

It is important to note that among environmental variables, total bird abundance was mostly affected by
Table 2 QAICc weights for explanatory variables

\begin{tabular}{llllllll}
\hline Variable & Species & \multicolumn{7}{l}{ Pairs } \\
\cline { 2 - 3 } & $\begin{array}{l}\text { All } \\
\text { species }\end{array}$ & $\begin{array}{l}\text { Alluvium- } \\
\text { dwellers }\end{array}$ & $\begin{array}{l}\text { Bank- } \\
\text { dwellers }\end{array}$ & & $\begin{array}{l}\text { All } \\
\text { pairs }\end{array}$ & $\begin{array}{l}\text { Alluvium- } \\
\text { dwellers }\end{array}$ & $\begin{array}{l}\text { Bank- } \\
\text { dwellers }\end{array}$ \\
\hline Regulation & 0.51 & 0.34 & 0.47 & & 0.27 & 0.34 & 0.28 \\
Vegetation & 0.47 & 0.34 & 0.22 & & 0.26 & 0.33 & 0.42 \\
Scarps & 0.48 & 0.30 & 0.43 & & 0.33 & 0.33 & 0.31 \\
Alluvia & 0.47 & 0.27 & 0.30 & & 0.23 & 0.21 & 0.27 \\
Woods & 0.47 & 0.24 & 0.27 & & 0.44 & 0.27 & 0.27 \\
\hline
\end{tabular}


a loss of deadwood (wood). It shows that deadwood is not only an important element in forests (e.g. for woodpeckers; Angelstam et al., 2003; Müller \& Bütler, 2010; Kajtoch et al., 2013a) but is also crucial for birds in riverine habitats. Moreover, after the removal of these natural elements and as a result of taming, which slows down water flow, some plant species, non-native to river channels, could have expanded and covered river channels. This led to the additional loss of suitable breeding places and could increase, for example, predation risk and/or decrease sources of food (e.g. Figarski \& Kajtoch, 2013; Kajtoch et al., 2013b). It is important to note that both habitat guilds (alluvium-dwellers and bankdwellers) were generally similarly affected by factors associated with habitat transformations (especially increased vegetation cover, scarp destruction and deadwood removal from river channels). For the number of pairs of alluvium-dwellers, REGULATION was a crucial factor that led not only to the retreat of some species from each river fragment but also to a decline in the numbers of remaining taxa. It is also interesting that for bank-dweller species, the expansion of vegetation was quite important. Regulation works not only have a direct influence on bank structures, but the alteration of the hydrological regime of rivers also drives important changes in their character (cover by plants). Such changes restrict the number of pairs that are able to breed.

In the European Union (EU), rivers are managed and protected under two principal directives: the Water Framework Directive (European Commission, 2000; Blöch, 1999; Kallis \& Butler, 2001; Chave, 2001) and the Habitat Directive (Council Directive, 1992; Evans, 2006; Paavola, 2004). Despite these regulations in "new" EU countries, river regulation and taming programmes still prevail under renaturalization actions (e.g. see the Polish Upper Vistula Flood Prevention Programme, Council of Ministers, 2011). In Poland such works increased in intensity and scale in the years after the 2010 flood. Hundreds of kilometres of river channels, especially in submontane areas, are being canalized and tamed. Unfortunately, this concerns not only previously regulated and tamed river sections, but also many others, even those natural in character, that had never been regulated before and are often protected as sites of community importance under the Natura 2000 network. These regulation and taming works make the protection of river habitats and species in "new" EU countries difficult, if not impossible. As a consequence, the European Commission has accused Poland of non-compliance with water directive and sent a letter of formal notice to Poland (November 2012) and then a reasoned opinion (April 2013) (European Commission, 2013). Recently (August 2014), the Polish government withdrew from continuation of the "Upper Vistula Flood Prevention Programme" (Council of Ministers, 2014).

Owing to the considerable sensitivity of aquatic ecosystems to disturbance of their hydrological regime, the opportunity to maintain or restore natural habitat types or species of community importance to a favourable conservation status can be very limited. The great work of habitat restoration accomplished by the flood of 2010 is being squandered. The actions undertaken for water control, that have involved river channel regulation and taming, have been harmful to natural values and should be replaced by a more modern approach to management that is compatible with EU directives and takes account of river ecosystem requirements. This is important as regulating and taming works are dangerous not only for riverine birds. Riverine habitats are some of the most important biodiversity hotspots and major routes of migration for organisms in Europe, so the degradation of riverine ecosystems can have a catastrophic impact on nature in the entire EU.

Acknowledgments We are grateful to two anonymous reviewers for their helpful comments.

Open Access This article is distributed under the terms of the Creative Commons Attribution License which permits any use, distribution, and reproduction in any medium, provided the original author(s) and the source are credited.

\section{References}

Allan, J. D. \& A. S. Flecker, 1993. Biodiversity conservation in running waters. BioScience 43: 32-43.

Angelstam, P., R. Bütler, M. Lazdinis, G. Mikusiński \& J.-M. Roberge, 2003. Habitat thresholds for focal species at multiple scales and forest biodiversity conservation - dead wood as an example. Annales Zoologici Fennici 40: 473-482.

Arthington, A. H., J. M. King, J. H. O'Keefe, S. E. Bunn, J. A. Day, B. J. Pusey, D. R. Bluhdorn \& R. Thame, 1991. Development of an holistic approach for assessing environmental flow requirements of riverine ecosystems. In Pigram, J. J. \& B. A. Hooper (eds), Water Allocation for the 
Environment: Proceedings of an International Seminar and Workshop. The Centre for Water Policy Research, University of New England, Armidale: 69-76.

Bibby, C. J., N. D. Burgess, D. A. Hill \& S. H. Mustoe, 2000. Bird Census Techniques, 2nd ed. Academic Press, London.

Blöch, H., 1999. The European Union Water Framework Directive: taking European water policy into the next millennium. Water Science and Technology 40: 67-71.

Bryce, S. A., R. M. Hughes \& P. R. Kaufmann, 2002. Development of a bird integrity index: using birds assemblages as indicators of riparian condition. Environmental Management 30: 294-310.

Burnham, K. P. \& D. R. Anderson, 2002. Model Selection and Multi-Model Inference: a Practical Information-Theoretic Approach. Springer-Verlag, New York.

Burnham, K. P. \& D. R. Anderson, 2004. Multimodel inference: understanding AIC and BIC in model selection. Sociological Methods \& Research 33: 261-304.

Castleberry, D. T., J. J. Cech Jr. \& D. C. Erman, 1996. Uncertainty and instream flow standards. Fisheries 21: 20-21.

Chave, P., 2001. The EU Water Framework Directive: An Introduction. IWA Publishing, London.

Council Directive, 1992. 92/43/EEC of 21 May 1992 on the Conservation of Natural Habitats and of Wild Fauna and Flora. Available at [http://ec.europa.eu/environment/ nature/legislation/habitatsdirective/].

Council of Ministers, 2011. Resolution 151/2011 of the Council of Ministers of 9 August 2011. Available at [http://www. malopolska.uw.gov.pl/doc/Uchwala_rady_ministroqw_nr_ 151_2011.pdf].

Council of Ministers, 2014. Resolution 1148/2014 of the Council of Ministers of 26 August 2014. [http://isap.sejm. gov.pl/DetailsServlet?id=WDU20140001148].

Croonquist, M. J. \& R. P. Brooks, 1991. Use of avian and mammalian guilds as indicators of cumulative impacts in riparian-wetland areas. Environmental Management 15: 701-714.

DesGranges, J.-L., J. Ingram, B. Drolet, C. Savage, J. Morin \& D. Borcard, 2006. Modelling wetland bird response to water level changes in the Lake Ontario - St. Lawrence River hydrosystem. Environmental Monitoring and Assessment 113: 329-365. (Special Issue: Canada's Ecosystem Initiatives).

European Commission, 2000. Directive 2000/60/EC of the European Parliament and of the Council of 23rd October 2000 Establishing a Framework for Community Action in the Field of Water Policy, Official Journal 22 December 2000 L 327/1, Brussels: European Commission. Available at [http://ec.europa.eu/environment/water/water-framework/].

European Commission, 2013. European Commission - MEMO/ 13/375 25/04/2013 411. Available at [http://europa.eu/ rapid/press-release_MEMO-13-375_en.htm].

Evans, D., 2006. The habitats of the European Union habitats directive. Biology and Environment 106: 167-173.

Figarski, T. \& Ł. Kajtoch, 2013. Kingfisher Alcedo atthis. In Zawadzka, D., M. Ciach, T. Figarski, Ł. Kajtoch \& Ł. Rejt (eds), Designation and Quality Evaluation of Bird Habitats in Natura 2000 Special Protection Areas. General Directorate for Environmental Protection, Warsaw: 253-260.

Freckleton, R. P., 2011. Dealing with collinearity in behavioural and ecological data: model averaging and the problems of measurement error. Behavioral Ecology and Sociobiology 65: 91-101.

Frederick, P., D. E. Gawlik, J. C. Ogden, M. I. Cook \& M. Lusk, 2009. The White Ibis and Wood Stork as indicators for restoration in the Everglades ecosystem. Ecological Indicators 9: 83-95.

Gregory, R. D., D. W. Gibbons \& P. F. Donald, 2004. Bird census and survey techniques. In Sutherland, W. J., I. Newton \& R. E. Green (eds), Bird Ecology and Conservation; a Handbook of Techniques. Oxford University Press, Oxford: 17-56.

Hill, M. T., W. S. Platts \& R. L. Beschta, 1991. Ecological and geomorphological concepts for instream and out-of-channel flow requirements. Rivers 2: 198-210.

Hughes, Rg. My \& R. F. Noss, 1992. Biological diversity and biological integrity: current concerns for lakes and streams. Fisheries 17: 11-19.

Hurvich, C. M. \& C.-L. Tsai, 1991. Bias of the corrected AIC criterion for underfitted regression and time series models. Biometrika 78: 499-509.

Johnson, W. C., R. L. Burgess \& W. R. Keammerer, 1976. Forest overstory vegetation and environment on the Missouri River floodplain in North Dakota. Ecological Monographs 46: 59-84.

Kajtoch, Ł., 2012. Znaczenie karpackich dolin rzecznych dla ptaków lęgowych: przykład zlewni Stradomki i Łososiny [importance of Carpathian river valleys for breeding birds: example of Stradomka and Łososina river's basins]. Chrońmy Przyrodę Ojczystą 68: 3-12.

Kajtoch, Ł. \& R. Bobrek, 2014. Range extension of the Goosanders into the Carpathians. Wildfowl 64: 91-101

Kajtoch, Ł. \& T. Figarski, 2013. Short-term revival of riverine bird assemblages after severe Flood. Bird Study 60: 327-334.

Kajtoch, Ł. \& A. Piestrzyńska-Kajtoch, 2008. Zmiany, zagrożenia i propozycje ochrony awifauny doliny środkowej Raby [changes, threats and proposition of protection of bird communities in the middle part of the Raba River valley (SE Poland)]. Chrońmy Przyrodę Ojczystą 64: 28-45.

Kajtoch, Ł., T. Figarski \& J. Pełka, 2013a. The role of structural elements of forests in determining the occurrence of two specialist woodpecker species in the Carpathians, Poland. Ornis Fennica 90: 23-40.

Kajtoch, Ł., T. Figarski \& M. Rejmer, 2013b. Common tern Sterna hirundo. In Zawadzka, D., M. Ciach, T. Figarski, Ł. Kajtoch \& Ł. Rejt (eds), Designation and Quality Evaluation of Bird Habitats in Natura 2000 Special Protection Areas. General Directorate for Environmental Protection, Warsaw: 209-214.

Kajtoch, Ł., M. Żmihorski \& A. Piestrzyńska-Kajtoch, 2014. The Goosander as potential indicator of naturalness and biodiversity in submontane river valleys of northern Carpathians. Ecological Indicators 45: 83-92.

Kallis, G. \& D. Butler, 2001. The EU water framework directive: measures and implications. Water Policy 3: 125-142.

Karr, J. R., L. A. Toth \& D. R. Dudley, 1985. Fish communities of midwestern rivers: a history of degradation. BioScience 35: 90-95.

Kingsford, R. T. \& R. F. Thomas, 2004. Destruction of wetlands and waterbird populations by dams and irrigation on the Murrumbidgee River in arid Australia. Environmental Management 34: 383-396. 
Mills, L. S., M. E. Soule \& D. F. Doak, 1993. The keystonespecies concept in ecology and conservation. Bioscience 43: 219-224.

Müller, J. \& R. Bütler, 2010. A review of habitat thresholds for dead wood: a baseline for management recommendations in European forests. European Journal of Forest Research 129: 981-992.

Naiman, R. J., J. J. Magnuson, D. M. McKnight, J. A. Stanford \& J. R. Karr, 1995. Freshwater ecosystems and management: A national initiative. Science 270: 584-585.

Nilsson, C. \& K. Berggren, 2000. Alterations of riparian ecosystems caused by river regulation. BioScience 50: 783-792.

Nilsson, C. \& M. Dynesius, 1994. Ecological effects of river regulation on mammals and birds: a review. Regulated Rivers: Research and Management 9: 45-53.

NRC - National Research Council, 1992. Restoration of Aquatic Systems: Science, Technology, and Public Policy. National Academy Press, Washington, D.C.

Paine, R. T., 1969. A note on trophic complexity and community stability. American Naturalist 103: 91-93.

Palacio-Núñez, J., R. J. Verdu, E. Galante, D. Jimenez-Garcia \& G. Olmos-Oropeza, 2007. Birds and fish as bioindicators of tourist disturbance in springs in semi-arid regions in Mexico: a basis for management. Animal Biodiversity and Conservation 3: 29-41.

Richter, B. D., J. V. Baumgartner, R. Wigington \& D. P. Braun, 1997. How much water does a river need? Freshwater Biology 37: 231-249.
Rood, S. B., C. R. Gourley, E. M. Ammon, L. G. Heki, J. R. Klotz, M. L. Morrison, D. Mosley, G. G. Scoppettone, S. Swanson \& P. L. Wagner, 2003. Flows for floodplain forests: a successful riparian restoration. Bioscience 53: 647-656.

Paavola, J., 2004. Protected areas governance and justice: theory and the European Union's Habitats Directive. Environmental Sciences 1: 59-77.

Sorace, A., P. Formichetti, A. Boano, P. Andreani, C. Gramegna $\&$ L. Mancini, 2002. The presence of a river bird, the dipper, in relation to water quality and biotic indices in central Italy. Environmental Pollution 118: 89-96.

Sparks, R. E., 1995. Need for ecosystem management of large rivers and floodplains. BioScience 45: 168-182.

Stanford, J. A., J. V. Ward, W. J. Liss, C. A. Frissell, R. N. Williams, J. A. Lichatowich \& C. C. Coutant, 1996. A general protocol for restoration of regulated rivers. Regulated Rivers: Research and Management 12: 391-414.

Toth, L. A., 1995. Principles and guidelines for restoration of river/floodplain ecosystems- Kissimmee River, Florida. In Cairns, J. (ed.), Rehabilitating Damaged Ecosystems, 2nd ed. Lewis Publishers/CRC Press, Boca Raton: 49-73.

Tyus, H. M., 1990. Effects of altered stream flows on fishery resources. Fisheries 15: 18-20.

Ward, J. V., K. Tockner \& F. Schiemer, 1999. Biodiversity of floodplain ecosystems: ecotones and connectivity. Regulated Rivers: Research and Management 15: 125-139.

Williams, J. G., 1996. Lost in space: minimum confidence intervals for idealized PHABSIM studies. Transactions of the American Fisheries Society 125: 458-465. 